\title{
The adaptive strategy in rendering the socio-communicative features of French colloquial lexemes in the Ukrainian translation of G. Musso's novel "Call from an Angel”
}

\author{
A. Bilas \\ Vasyl Stefanyk Precarpathian National University, Ivano-Frankivsk, Ukraine \\ Corresponding author. E-mail: bilas_andriy@ukr.net
}

Paper received 22.08.18; RAccepted for publication 28.08.18.

https://doi.org/10.31174/SEND-Ph2018-177VI52-01

\begin{abstract}
The article deals with socio-communicative aspect of colloquial language as a translation problem. The adaptive strategy in translating French colloquial words is examined. The procedures and techniques of rendering the colloquial component of G. Musso's novel "Call from an Angel" in the Ukrainian translation are analysed.

Keywords: colloquial language, connotation, translation, functionality, truncation, rendering, adaptation, strategy, procedure, procedure.
\end{abstract}

Introduction. The study of translation activities, aimed to achieve the adequacy of translation, is one of the fundamental issues of modern translation. The adaptive translation strategy, as a way of overcoming the interlingual and intercultural asymmetry, provides a set of translation tactics that help to transfer the pragmatic potential of the source, the author's intentions and avoid interference in translation. Linguistic and cultural asymmetry between the recipients of the original and translation texts determines the application of an adaptive strategy in translating the fiction text. Adaptive translation strategy consists in adding, eliminating and replacing the source text elements [5, p. 85-87].

An analytical review of various definitions of the term "adaptation" shows that current and, accordingly, common in modern translation science is the understanding of adaptation as an important creative component of translation process, aimed at providing a functional and complete replacement of the source text. Similar translation activities aimed to achieving the adequacy of the translation due to the neutralization of the language and cultural barrier of the original and translation texts are called "pragmatic" [7], or "linguo-cultural" adaptation of the source text $[5 ; 6]$.

The goal. This article aims not only at examining adaptation as translation strategy, but also at analysing and demonstrating the basic adaptive techniques of French low colloquial units of different registers used by $\mathrm{K}$. Yermolayeva in translating the G. Musso's novel "Call from an Angel".

Materials and methods. A descriptive method with some techniques of contextual analysis and synthesis is used for the systematic description of illustrative and theoretical material. The method of translation studies analysis was used to identify regular matches and translation deviations from the original text. The sample collection method gave an opportunity to identify and organize the necessary language units. The methods of linguistic, stylistic and comparative analysis were applied to determine the typical paradigmatic and stylistic features of the low colloquial elements and their translation. The contextual analysis and the method of component analysis helped to determine the explicit and implicit connotative components of the structure of the studied units in the original text and the specifics of their reproduction in translation.

A brief review of publications on the subject. We start with an attempt to clarify the notion of adaptation in translation studies. In this case, is it possible to say that adaptation does not have the right to exist in today's theory and practice of translation? As it turns out, the concept "adaptation" is ambiguous [7]. On the one hand, it exists its various definitions. On the other hand, they clearly emphasize the significance of adaptation's domesticating nature. H. Vandal-Sirois and G.L. Bastin pay attention to the applying of adaptation in practice [16, p. 26]. They also note that adaptations take place on the cultural or pragmatic levels at least as much as on the linguistic or textual level.

L.L. Neliubyn defines adaptation in as a technique of creating correspondences by changing the described situation in order to achieve the same effect on the receptor $[4$, p. 12]. Adaptation as a means of convergence of two linguistic and cultural realities in translating has the entire right to exist, as evidenced by numerous translations of H. Kochur, who widely uses tactics of substitution to adapt the translated text to the norms of the target language, with the preservation of the original versifying system and rhythm [7]. H. Kochur protects the preserving the authenticity of the original in the translation, criticizing the "smoothing" of the translation language, because "the heroes are speaking, not writing treatises": "a writer gets down hardly from the right path and allows him some kind of obscenity, how to intervene: to eliminate a dangerous place or rewrite it so that it corresponds to our idea of a good practice" [2, p. 565].

Thus, we conclude that the method of rendering the colloquially marked elements of a foreign fiction text by means of Ukrainian may not be one vector. On the one hand, it is not necessary to simplify the live language of the source, but to use all the lexical diversity of Ukrainian, without forgetting dialect and vernacular words. And on the other hand, "over colouring" and domestication of translations are not appropriate [1, p. 101]

Adaptation is very peculiar and differs in many ways from any other translative strategies. It may "be understood as a set of translative interventions which result in a text that is not generally accepted as a translation but is nevertheless recognized as representing a source text" $[8$, 
p. 3]. The nature of adaptation is such that "may embrace numerous vague notions such as appropriation, domestication, imitation, rewriting, and so on" [8, p. 3].

In fact, the notion of adaptation was discussed, supported or severely criticized in the field of translation studies and often called 'an abusive form of translation' $(16$, p. 21). H. van Gorp suggests that the concept of all adaptation has "gradually acquired more the negative connotations" comparing to translation $[14, \mathrm{p} .1]$. Then, he continues that if translation eats an ideal image of a source next adaptation potentially subverts that image (10, p. $66 ; 14$, p. 1).

It is important to note that adaptation as one of a number of translation strategies, adaptation can be defined in a technical and objective way. Perhaps, one of the first definitions of the notion of adaptation is J.-P. Vinay and J. Darbelnet's, who list adaptation s heir seventh translation procedure: adaptation is a procedure which can be used whenever he context referred to in the original text does not exist in the culture of the target text, thereby necessitating some form of re-creation [8, p. 3].

In Translation Studies we can assume without any doubts that adaptation is the most efficient communicational strategy. Although it is a tactical tool used to solve isolated communicational problems or conflicts. G.L. Bastin examines the implications of adaptation as tactical and strategic ways of solving cultural dissimilarities from the translation studies perspective. G.L. Bastin shows that adaptation in translation studies is at the crossroads of various disciplines that it can enrich [9, p. 73]. Developing the theory of M. Tymoczko [15] L. Raw proposes an extension of intellectual field that will 'expend the conception of translation [and adaptation], moving it beyond dominant, parochial, and stereotypical thinking about [...] processes and products' [14, p. 3].

Results and discussion. Adaptation has always been defined in relation to something else - a specific style, linguistic conventions or a communication model. Translation studies as an independent discipline now enables us to study adaptation on its own terms, as both a local and a global procedure. It is imperative to acknowledge adaptation as a type of creative process which seeks to restore the balance of communication that is often disrupted by traditional forms of translation. Only by treating it as a legitimate strategy can we begin to understand the motivation for using it and to appreciate the relationship between it and other forms of conventional translation [8, p. 3-6].

J. R. Morton Gledhill focuses on a strategic approach to translation, observing its fundamental aspect due to many forms of translation, all of which have their validity depending the translator's aims and circumstances. These range from close translation to recreations and include intermediary stages such as adaptations [12, p. 5]. He also insists on the importance of semantic and communicative adaptation as one of many factors (target readership, publishing contract, general strategy domesticating and rewriting) influencing the strategic approach [12, p. 143].

G.L. Bastin defines the most common factors or conditions which cause translators to resort to adaptation (8, p. 5): 1) cross-code breakdown: where there are simply no lexical equivalents in the target language (especially common in the case of translating metalanguage); 2) situational or cultural inadequacy : where the context or views referred to in the original text do not exist or do not apply in the target culture; 3 ) genre switching : a change from one discourse type to another (e.g. from adult to children's literature) often entails a global re-creation of the original text; 4) disruption of the communication process : the emergence of a new epoch or approach or the need to address a different type of readership often requires modifications in style, content and/or presentation.

The conditions of applying adaptation (cross-code breakdown, situational or cultural inadequacy, genre switching, disruption of the communication process), which in practice may exist simultaneously, can lead to two major types of adaptation: local adaptation, caused by problems arising from the original text itself and limited to certain parts of it (as in the first two conditions), and global adaptation, which is determined by factors outside the original text and which involves a more wide-ranging revision $(8$, p. 5$)$.

Adaptive strategy involves three main actions (tactics) of the translator: various substitutions of elements of the source text, elimination of some elements and addition of new elements. As for substitutions, they may have a synonym character (instead of the direct equivalent, an interlingual synonym (analogue) of the original word is used), hyponymic and hyperonymic character (a unit of the original text is replaced by a hyponym or hyperonym, resulting in a semantic transformation of concretisation or generalisation). In addition, the translation substitutions may become antonymic, and also use modulations related to changing the vector of semantic relations (for example, conversion of cause and consequence and vice versa) [7].

T. Volkova and M. Zubenina point out that sociocultural adaptation tends to be viewed in terms of techniques and strategies of pragmatic adaptation (omission, expansion, exoticism, updating and creation, and pragmatic strategies include explicitness change, interpersonal change, illocutionary change, coherence change, partial translation, visibility change, and transediting) [17, p. 104]. Although thee argue that sociocultural adaptation techniques may be illustrated by transcription / transliteration, generalization, translation y more neutral equivalents, translation by cultural substitution, translation using a loan word, translation by paraphrase, translation by omission / edition, translation by illustration, functional equivalence, formal equivalence, and descriptive translation [17, p. 104].

In terms of mode of adaptation, G.L. Bastin proposes to distinguish following procedures used by the translator: 1) transcription of the original (word-for-word reproduction of part of the text in the original language, usually accompanied by a literal translation); 2) omission (the elimination or implicitation of part of the text); 3) expansion: the addition or explicitation of source information, either in the main body or in a foreword, footnotes or a glossary; 4) exoticism (the substitution of stretches of slang, dialect, nonsense words, etc. in the original text by rough equivalents in the target language); 5) updating (the replacement of outdated or obscure information by modern equivalents); 6) situational or cultural adequacy (the recreation of a context hat is more familiar or culturally appropriate from the target reader's perspective than the 
one used in the original); 7) creation (a more global replacement of the original text with a text that preserves only the essential message/ideas/functions of the original) $[8$, p. 5].

As for rendering of multi-register colloquial speech in the translation we propose to identify the socio-cultural adaptive strategy including linguo-register, sociocommunicative, socio-stylistic, linguo-cultural and sociolinguistic translation tactics. Linguo-register tactics involves the use of appropriate adaptives: the replacement of the original register by the same or equivalent register of the target language, the replacement of the lower to the higher register, the replacement of the higher to the lower register. Socio-communicative adaptation provides situational, occasional, variational/synonymous adaptives. Social-figurative equivalent, analogue and calque we distinguish in the arsenal of socio-stylistic adaptation. Socio-linguistic adaptation contains complete and partial formal adaptives and transformations. Notional, conceptual, semantic adaptives fill linguo-cultural adaptation.

Thus, we study in details the characteristics of fiction heroes' colloquial speech that leads to different adaptations, namely the marks of spoken language, the lexical register, cultural references and playful aspects. The use of low colloquial words is not only in characters' speech, but in the author's language. It complicates the understanding of socio-communicative and aesthetic function of low colloquial units in a fiction text by French speaking people and especially by foreign recipients. In this case translators use some techniques of adaptive strategy. For example, translating the G. Musso's novel "Call from an Angel” K. Yermolayeva use full form (колишній "а former partner") of the truncated word ex ("a former partner"): Vous y avez camouflé ceux de vos ex [13]... - Bu заховали там номери своїх колишніх [3, p.6]...

Even without this preliminary analysis, the translator feels instinctively that he cannot literally translate a certain number of stylistic marks, which obviously seem unacceptable in target language (in our case - Ukrainian). That's why he/she is forced to consider the stylistic marks of low colloquial French (e.g. truncated lexemes) as a cultural characteristic to adapt to the Ukrainian public. Therefore, translators have difficulties in rendering different types of French colloquial truncated lexemes. Particularly the translator of Musso's novel uses full forms of the truncated words that causes the loss of colloquial colouring not only of a separate word but also of the whole text and it can be illustrated by the truncated unit parano and ch'ais: 1. Ne sois pas parano [13]! Не будь параноїком [3, p.8]! 2. - Ch'ais pas [13]. - Та не знаю я [3, p.59].

In the case of the translation of colloquial words, the best option available seems to lie in a strategy that ensures performing the same function of the original as well as rendering its communicative effect regardless of formal considerations on the syntactic and lexical levels. Functional equivalence means using an equivalent in the target language culture whose function is similar to that of the source language culture: C'était sympa d'avoir toujours sur soi une photo rigolote à montrer aux collègues [13]. Це ж так прикольно, завжди мати із собою смішну фотку, аби показати колегам [3, p. 6]. An examination of the Ukrainian translation shows that the translator uses a combination of functional equivalence plus compensa- tion, because смішна is not colloquial word but фотка is colloquial.

If there is a conflict between the source language culture and target language culture having the different cultural imaginations, the translator should put the target language readers' acceptance at the first place to achieve the functional equality, as we can observe in the case with colloquial denominations of people (conne, abruti, nana): 1. Quelle conne [13]! - Hy ü dypena! [3, p. 18]. 2. Quel abruti [13]! - Om кретин [3, p. 18]! 3. - Eh! pas mal la папа [13]! - Овва! Ладна краля [3, р. 30]!

Often, the translator applies the replacement of the original register by the same or similar register of the target language: 1. - OK, tu gagnes cette manche [13]...Ок, ией раунд ти виграла [3, p. 12]! 2. - Cap à l'est, moussaillon [13]! - Курс на схід, юнго [3, р. 17]! 3. Allez, Jon', sois cool [13]! - Ну Джоне, будь кльовим $[3$, p. 27]!

Language varieties and registers are of great importance for the translation of colloquial lexemes. Thus, it is important for the translator to be aware of the linguistic and socio-linguistic elements in translating in general and in translating colloquial words in particular. Occasionally, the translator replaces a source argot word by a target argot word: - Tu es mon seul vrai copain, mon seul vrai ротеаи [13]... - Ти мій єдиний справжній друг, мій єдиний справжній кореш [3, p. 37]... As we can see, poteau "friend" is adapted in Ukrainian кореш with the same meaning, but borrowed from Russian argot vocabulary.

Adaptation plays a key role in translating colloquial words. However, we are dealing with adaptation that reduces the translated text effect on its reader. It is a case of the replacement procedure of the lower to higher register, which is not rare observed during our examination of the K. Yermolayeva's translation of the G. Musso's novel "Call from an Angel". The translator does the tone of the text higher, but tries to give it the flavour of natural usage, adapting it to target language recipient: 1. - Bon sang, que cette théière est lourde [13]! - Господи, який же ией чайник важкий [3, p. 18]... 2. Dans la cuisine, en haut d'un placard, vous allez chercher le vieux paquet de clopes entamé que vous avez planqué là en cas de coup dur [13]. - На кухні, в шафі нагорі, ви шукаєте стару розпочату пачку цигарок, що заховали колись на чорний день [3, p. 7]. 3. - Envoie-moi Charly et casse-toi ! ordonna-t-il, à cran [13]. - Відправ мені Чарлі та забирайся! - наказав він, ледь стримуючись [3, р. 14].

So, to recreate in another language, which does not have the same register structure as the source language, an equivalent in the target language, the translator refers to effacing the text strangeness instead of finding atypical forms in the target language: C'est quoi cette embrouille ? pensa-t-il en relisant le SMS. Une blague loufoque de Marcus [13]? - Що за нісенітниця? - подумав він, перечитуючи смс. Недолугий жарт Маркоса [3, р. 20]?

Considering the fact that the samples examined in this study were colloquial or informal in tone, this question mainly was related to the degree of the success of the translators in preserving the informal tone or register of 
the original text: - Tu as pigé, Fangio [13]? - Bmoponas, Фанхіо [3, p. 324]?

As well known, the adaptation procedures used, are, to some extent, dependent on translators' taste, their knowledge and their faithfulness to the source text. It is worth mentioning that all adaptive procedures are frequent in the analysed translation text. It is the case of adaptation using a borrowing or loan word. It happens that K. Yermolayeva uses loan word, not French, but English and Russian, in adapting colloquial lexemes, e.g. oфic (office), копи (cops), хош (from vernacular Russian хотеть "to want"): 1. Vous vérifiez à nouveau sans plus de succès, essayant de vous persuader que vous l'avez oublié au bureau, mais... non: vous vous souvenez de l'avoir consulté dans l'ascenseur en quittant le boulot [13]... - Ви знов перевірясте, звичайно, без жодного yсnіху, намагаєтесь вмовити себе, щуо забули його на роботі, але..на: ви точно пригадуєте, як користувалися ним у ліфті, виходячи з офісу... [3, p. 7]. 2. - ...Mais qu'est-ce que tu crois ? Que c'était facile ?... J'étais dans une impasse : les flics sur le dos, les gangs rivaux qui voulaient ma peau [13]... - Але щзо ти собі думаєш? Що ие так просто? Я був у безвиході: копи на хвості, ворожі банди, щзо полюють на мою икуру [3, p. 288]... 3. - T'as pas sommeeeiiil [13]? Спати не хош [3, p. 38]?

Sometimes, K. Yermolayeva has intention to reproduce the precise contextual meaning of the translation eliminating the source picture. She adapts metaphorically formed colloquial expression moule à gaufres by functional equivalent придурок: - Moule à gaufres [13]! Придурок [3, p. 38]!

In another case the translator adapts colloquial lexeme dingue with adding the situationally concreted meaning: Non, tu es dingue [13]! - Hi, ти з глузду з'їхав [3, p. 309]!

In some cases the translator should recreate a situation that can be regarded as more or less equivalent. From this outlook, adaptation is a specific kind of situational or occasional equivalence as we can see in the examples below: 1. Elle a travaillé en infiltrée chez les narcos [13]. - Вона працювала під прикриттям серед наркоторговців [3, p. 308]. 2. - Si vous le tuez, vous êtes foutue [13]! - Уб'єте його - i вам гаплик! [3, p. 313]. 3. - Pour la dernière fois, reculez ou je le flingue! Les agents du FBI, je m'en tape, j'ai dix portes de sortie pour les semer [13]. - Останній раз кажу: відступіть, або я знесу йому голову! Чхала я на агентів ФБр, у мене є купа шляхів для відступу [3, p. 313].

As a frequent adaptive procedure synonymy is used as an ideal situation to reflect the translator success in correct transference of the source language concepts. It is significant that not all the synonymies in the target texts in question are complete due to the difference in their register. In some cases, the translator decides to sacrifice the connotative meaning for transferring the semantic meaning not preserving the informal tone of the source text [11, p.1019]: 1. Bordel ! ... C'est le téléphone de la greluche de JFK [13]! - Дідько! ... Це телефон тієї навіженої JFK [3, p.20]! 2. - Et merde ! ... C'est le téléphone du cinglé de l'aéroport [13]! - O же ж лайно! ... Це телефон того психа з аеропорту [3, p.21]!

As can be seen, the colloquial denomination of a car "titine" is rendered with different and more concrete colloquial equivalents in Ukrainian. The translation refers to an identical situation as its source and the Ukrainian equivalents express the same conception of reality (titine "car") with different images (кралечка "beautiful girl"; машинка "little car"): 1. - Mais non, elle ronronne ma titine... Si tu savais comme je la bichonne [13]! - Ta нi, он як вона муркотить, моя кралечка! ... Знав би ти, як я з неї пилинки здмухую [3, p. 24]! 2. Il [Marcus] se concentra sur sa conduite pour rejoindre Columbus Avenие et garer sa "titine » [13]... - Він зосередився на керуванні автівкою, аби дістатися Колумбус-авеню та припаркувати свою «машинку»... [3, p. 26]. So, titine is adapted into Ukrainian version, replacing the source language image with target language image which is familiar to the Ukrainian readers.

Conclusions. Finally, it should be pointed out that the socio-cultural adaptive strategy includes linguo-register, socio-communicative, socio-stylistic, linguo-cultural and socio-linguistic translation tactics. Linguo-register tactics involves the use of appropriate adaptives: the replacement of the original register by the same or equivalent register of the target language, the replacement of the lower to the higher register, the replacement of the higher to the lower register. Socio-communicative adaptation provides situational, occasional, variational/synonymous adaptives. Social-figurative equivalent, analogue and calque we distinguish in the arsenal of socio-stylistic adaptation. Socio-linguistic adaptation contains complete and partial formal adaptives and transformations. Notional, conceptual, semantic adaptives fill linguo-cultural adaptation.

We may conclude that socio-cultural and sociolinguistic adaptation may be provided by different techniques depending on the colloquial component variety in the source text, the translator skills and intentions and the target language colloquial resources. Consequently, a translator may use the following procedures: transcription, transliteration, translation by more neutral equivalents, cultural substitution, translation using a loan word, paraphrase, omission, addition, functional equivalence, formal equivalence descriptive translation and others. The procedures may be used, depending on translator's taste, his/her knowledge and his/her faithfulness to the source text.

\section{ЛІТЕРАТУРА}

1. Білас А. До перекладацької методики Григорія Кочура: відтворення розмовно маркованого компонента художнього тексту засобами цільової мови // Іноземна філологія, 2014. Вип. 127, Ч. 2. С. 98-103.

2. Кочур Г. Марія Габлевич [Про рецензію на переклад роману Апдайка «Ферма»] // Кочур, Григорій. Література та переклад: Дослідження. Рецензії. Літературні портрети. Інтерв'ю / Упоряд. А. Кочур, М. Кочур; Передм. I.

Дзюби, Р. Зорівчак, Київ, Смолоскип, 2008, Т. 1. С. 564565.

3. Мюссо Г. Поклик янгола, Роман, Харків, Клуб Сімейного Дозвілля, 2015. 352 с.

4. Нелюбин Л. Л. Толковый переводоведческий словарь. Изд. 5-е, Москва, Флинта-Наука, 2008. С. 12-13.

5. Сопилюк Н. Адаптивна стратегія при перекладі художнього тексту (на матеріали творів М. Пруста) // Актуальні 
питання суспільних наук та історії медицини, 2017. № 1. C. $85-88$.

6. Сопилюк Н. М. Системні розбіжності між мовами як чинник застосування лінгвокультурної адаптації у міжкультурній комунікації // Вісник Луганського національного університету імені Тараса Шевченка. Філологічні науки, 2013, №14(1). С. 126-131.

7. Чередниченко О. Перекладацький доробок Григорія Кочура (до 100-літнього ювілею Майстра) // Всесвіт, 2009. №5-6. C. 185-191. http://www.vsesvitjournal.com/old/content/view/578/41/

8. Bastin G.L. Adaptation // Baker M., Saldahna G. Routledge Encyclopedia of Translation Studies, New York, Routledge, 2011. P. 3-6.

9. Bastin G.L. Adaptation, the Paramount Communication Strategy // Linguaculture, 2014. № 1. P. 73-87.

10. Gorp H.,Van. Translation and comparable transfer operations // Übersetzung. Translation. Traduction. An International Encyclopedia of Translation Studies. H. Kittel et al. (eds), 2004. Vol.1, Berlin and New York, Walter de Gruyter. P. 62-68.

11. Jalalpour E., Heidari Tabrizi H. A Study of English Translation of Colloquial Expressions in Two Translations of Jamalzadeh: Once Upon a Time and Isfahan Is Half the World // Journal of Language Teaching and Research, 2017. Vol. 8, No. $\quad$ 5,
http://dx.doi.org/10.17507/jltr.0805.24

12. Morton Gledhill, J. R. (2001). Strategies in Translation: A Comparison of the Helen Lowe-Porter and David Luke Translations of Thomas Mann's Tonio Kröger, Tristan and Der Tod in Venedig within the Context of Contemporary Translation Theory, Dissertation, Hudders Field, Erfurt. 281 p.

13. Musso G. L'Appel de l'ange, Roman, Paris, XO éditions, 2011. $400 \mathrm{p}$.

14. Raw L. Introduction: Identifying Common Ground // Translation, Adaptation and Transformation, Ed. L. Raw, London and New York, Continuum, Bloomsbury Publishing, 2012. P. $1-20$.

15. Tymoczko M. Enlarging Translation, Empowering Translations. New York: St Jerome Publishing, 2007. 362 p.

16. Vandal-Sirois H., Bastin G.L. Adaptation and Appropriation: Is there a Limit? // Translation, Adaptation and Transformation. Ed. L. Raw, London and New York, Continuum, Bloomsbury Publishing, 2012. P. 21-41.

17. Volkova T., Zubenina M. Pragmatic and Sociocultural Adaptation in Translation: Discourse and Communication Approach // SKASE Journal of Translation and Interpretation. 2015, Vol. 8, no. 1. P. 89-105. http://www.skase.sk/Volumes/JTI09/pdf_doc/05.pdf

\section{REFERENCES}

1. Bilas A. Hryhoriy Kochur's Translation Methods: Rendering the Colloquially Marked Component of Fiction Text by the Target Language Resources // Foreign philology, Is. 127, Part 2, 2014. P. 98-103.

2. Kochur H. Maria Hablvych [On the Review of the Translation of the Novel of the Updike "Of the Farm"] // Kochur, Hryhory. Literature and Translation: Researches. Reviews. Literary portraits. Interviews / Ed. A. Kochur, M. Kochur; Preface by I. Dziuba, R. Zorivchak. Kyiv, Smoloskyp, 2008. Vol. 1. P. 564-565.

3. Musso G. Call from an Angel, Roman, Kharkiv, Family Leisure Club, 2015. 352 p.

4. Nelyubin L.L. Translation Studies Dictionary. Ed. $5^{\text {th }}$, Moscow, Flinta-Nauka, 2008. P. 12-13.

5. Sopylyuk N. Adaptive Strategy in Literary Translation (on the Material of Marcel Proust's Prose) // Current Issues of Social Sciences and History of Medicine, 2017. Is. 1. P. 85-88.

6. Sopyliuk N. M. System Language Differences as a Factor Determining Linguo-Cultural Adaptation in Intercultural Communication // Visnyk Journal of Taras Shevchenko National University of Lugansk. Philological Sciences, 2013. Is. 14(1). P. 126-131.

7. Cherednychenko O. Translation Work of Grygory Kochur (to the 100th anniversary of Master) // Vsesvit, 2009. Is. 5-6. P 185-191. journal.com/old/content/view/578/41/

8. Bastin G.L. Adaptation // Baker M., Saldahna G. Routledge Encyclopedia of Translation Studies, New York, Routledge, 2011. P. 3-6.

9. Bastin G.L. Adaptation, the Paramount Communication Strategy // Linguaculture, 2014. № 1. P. 73-87.
10. Gorp H.,Van. Translation and comparable transfer operations // Übersetzung. Translation. Traduction. An International Encyclopedia of Translation Studies. H. Kittel et al. (eds), 2004. Vol.1, Berlin and New York, Walter de Gruyter. P. 62-68.

11. Jalalpour E., Heidari Tabrizi H. A Study of English Translation of Colloquial Expressions in Two Translations of Jamalzadeh: Once Upon a Time and Isfahan Is Half the World // Journal of Language Teaching and Research, 2017. Vol. 8, No. $5, \quad$ P. $1011-1021, \quad$ DOI: http://dx.doi.org/10.17507/jltr.0805.24

12. Morton Gledhill, J. R. (2001). Strategies in Translation: A Comparison of the Helen Lowe-Porter and David Luke Translations of Thomas Mann's Tonio Kröger, Tristan and Der Tod in Venedig within the Context of Contemporary Translation Theory, Dissertation, Hudders Field, Erfurt. 281p. 13. Musso G. L'Appel de l'ange, Roman, Paris, XO éditions, 2011. $400 \mathrm{p}$.

14. Raw L. Introduction: Identifying Common Ground // Translation, Adaptation and Transformation, Ed. L. Raw, London and New York, Continuum, 2012. P. 1-20.

15. Tymoczko M. Enlarging Translation, Empowering Translations. New York: St Jerome Publishing, 2007. 362 p.

16. Vandal-Sirois H., Bastin G.L. Adaptation and Appropriation: Is there a Limit? // Translation, Adaptation and Transformation. Ed. L. Raw, London and New York, Continuum, 2012. P. 21-41

17. Volkova T., Zubenina M. Pragmatic and Sociocultural Adaptation in Translation: Discourse and Communication Approach // SKASE Journal of Translation and Interpretation. 2015, Vol. 8, no. 1. P. 89-105. http://www.skase.sk/Volumes/JTI09/pdf_doc/05.pdf 